\title{
Raising Awareness of Abdominal Compartment Syndrome after Gynecologic-Oncology Surgery
}

\author{
Jinekolojik-Onkoloji Cerrahisi Sonrası Abdominal Kompartman Sendromu Farkındalığını Artırma
}

Gunsu Kimyon, Eylem Unlubilgin, Zeynep Ucar, Osman Turkmen, Alper Karalok, Tolga Tasci, Selcan Sınacı

Gokhan Tulunay, Nurettin Boran

Etlik Zubeyde Hanim Women's Health Teaching and Research Hospital, Gynecologic Oncology Division, Ankara, Turkey

\begin{abstract}
A 56 years old female, body mass index $44 \mathrm{~kg} / \mathrm{m}^{2}$, postmenopausal patient who had a solid mass of approximately $6-\mathrm{cm}$ in diameter at the left adnexal area underwent laparotomy with vertical incision. Staging surgery was performed because of the frozen section result that was reported as a malignant ovarian cancer. On the postoperative $2^{\text {nd }}$ day, the patient had dyspnea, cold sweats, tachycardia, tachypnea and bowel sounds were detected as hypoactive. $\mathrm{SO}_{2}$ was measured as $88 \%$ during follow-up and right costophrenic angle was appearing blunt in her chest X-ray. Arterial blood gas analysis results were as follows; ph: 7.41, $\mathrm{PCO}_{2}: 29.2 \mathrm{mmHg}, \mathrm{SO}_{2}: 86 \%, \mathrm{HCO}_{3}$ : $18.2 \mathrm{mmol} / \mathrm{L}$, and base excess (BE): $-4.9 \mathrm{mmol} / \mathrm{L}$. There was no additional feature in the blood cell counts and biochemical tests. The diagnosis of pulmonary emboli was ruled out with thoracic spiral tomography. In the sequel, the patient began vomiting, while her bowel sounds were remained hypoactive with addition of abdominal distension. After the initial intravesical pressure (IVP) was measured as $16 \mathrm{mmHg}\left(22 \mathrm{~cm} \mathrm{H}_{2} \mathrm{O}\right)$ manually, the patient was observed with endoluminal decompression methods and medical management. The clinical signs and physical examination findings did not improve; IVP measured two hours later was $21 \mathrm{mmHg}\left(28 \mathrm{cmH}_{2} \mathrm{O}\right)$. Because of these clinical findings and the rise of sequential IVP measurements, the patient was diagnosed with abdominal compartment syndrome. Decompressive laparotomy was performed and completed by closing the skin without suturing the fascia. Eight months later, her overall condition was good and follow-up has continued. Monitoring intraabdominal pressure with intermittent indirect IVP measurements in intensive care patients with high risk for ACS has great significance for early diagnosis, increasing the awareness for this condition. Early decompressive surgery in ACS is the life-saving step.
\end{abstract}

Key Words: Abdominal compartment syndrome, intraabdominal hypertension, intravesical pressure measurement

Received: 02.29.2016

Accepted: 04.05.2016
ÖZET

Elli altı yaşında, vücut kitle indeksi $44 \mathrm{~kg} / \mathrm{m}^{2}$ olan sol adneksiyel alanda yaklaşık $6 \mathrm{~cm}$ solid kitleye sahip postmenopozal hastaya vertikal insizyon ile yapılan laparotomide intraoperatif patoloji sonucunun malign over tümörü olarak rapor edilmesi üzerine hastaya evrelendirici cerrahi uygulandı. Postoperatif 2. Günde, hastada dispne, soğuk terleme, taşikardi, taşipne gelişmiş ve barsak sesleri hipoaktif olarak saptandı. Takipte $\mathrm{SO}_{2} \% 88^{\prime}$ di ve akciğer direk grafide sağ kostafrenik alan künttü. Arteriyel kan gazı sonucunda ph: 7.41, $\mathrm{PCO}_{2}: 29.2 \mathrm{mmHg}, \mathrm{SO}_{2}: \% 86, \mathrm{HCO}_{3}: 18.2 \mathrm{mmol} / \mathrm{L}$, ve baz açı̆̆ı: $-4.9 \mathrm{mmol} / \mathrm{L}$ idi. Spiral tomografi ile pulmoner emboli tanısı dışlandı. Hastanın mevcut bulgularına kusma ve abdominal distansiyon eklendi. Başlangıç intravezikal basıncın (IVB) manuel olarak $16 \mathrm{mmHg}\left(22 \mathrm{cmH}_{2} \mathrm{O}\right)$ saptanması üzerine hasta endolüminal dekompresyon metodları ve medikal yönetim ile takip edildi. Klinik bulgularda ve fizik muayenede gerileme olmaması üzerine 2 saat sonra ölçülen IVB $21 \mathrm{mmHg}\left(28 \mathrm{cmH}_{2} \mathrm{O}\right)$ idi. Hastaya abdominal kompartman sendromu tanisıyla dekompresif laparatomi uygulandı ve fasya açık bırakılıp sadece cilt onarımı ile operasyon tamamlandı. Hasta postoperatif 8 . ayda hastalıksız olarak yaşamına devam etmekteydi. AKS açııından yüksek riske sahip yoğun bakım hastalarında aralıklı indirekt IVB ölçümü ile intraabdominal basınç monitorizasyonu AKS farkındalı̆ını arttırma ve erken tanı açııından büyük öneme sahiptir. AKS'de erken dekompresif cerrahi hayat kurtarıcı basamaktır.

Anahtar Sözcükler: Abdominal kompartman sendromu, intraabdominal hipertansiyon, intravezikal basınç ölçümü

Geliş Tarihi: 29.02.2016

Kabul Tarihi: 05.04.2016

\section{INTRODUCTION}

Abdominal compartment syndrome (ACS) is a progressive clinical condition characterized by the persistent increase in intraabdominal pressure (IAP) that may result in sepsis and even multiple organ failure. The increased intraabdominal pressure causes reduced venous return and cardiac output resulting in end-organ hypoperfusion and ischemia, and intestinal ischemia leads to translocation of microorganisms, giving rise to sepsis (1). The World Society of the Abdominal Compartment Syndrome
(WSACS) defines intraabdominal hypertension (IAH) as sustained or repeated pathologic elevation of IAP $\geq 12 \mathrm{mmHg}$, and ACS as a sustained IAP >20 $\mathrm{mmHg}$ that is associated with new organ dysfunction (2). IAH is categorized as follows: Grade I: IAP 12-15 mmHg; Grade II: IAP 16-20 mmHg; Grade III: IAP 21- $25 \mathrm{mmHg}$; and Grade IV: IAP $>25 \mathrm{mmHg}$ (3). Diagnosis is not made upon a single measurement and successive measurements are required. In contrast to IAH, ACS is not graded. 
Clinical manifestations of ACS include abdominal distention, abdominal rigidity, tachypnea or hyperpnea, loss of diaphragm movements, hypotension, tachycardia, weak or thin pulse, oliguria or anuria, cold extremities, flat neck veins, and altered consciousness (1).

The incidences of IAH and ACS among general intensive care patients are $25 \%$ (range: $10-32 \%$ ) and $4 \%$, respectively $(4,5)$. The incidence of IAH among surgical intensive care patients reaches $65 \%$ (6). In this article, we present a case with abdominal compartment syndrome that developed after abdominal surgery performed for staging ovarian carcinoma.

\section{CASE REPORT}

A 56 years old postmenopausal patient presenting with abdominal pain had goiter and diabetes mellitus in her medical history. Her body weight was $120 \mathrm{~kg}$, yielding a body mass index (BMI) of $44 \mathrm{~kg} / \mathrm{m}^{2}$. Upon physical examination and imaging studies, a solid mass of approximately $6-\mathrm{cm}$ in diameter was detected at the left adnexal area. Tumor markers were elevated (CA125: $497 \mathrm{IU} / \mathrm{ml}, \mathrm{CA} 19-9: 162 \mathrm{lU} / \mathrm{ml})$. Due to an initial diagnosis of pelvic mass, laparotomy was performed with a vertical incision. Intraoperative inspection revealed diffuse tumor dissemination and frozen section examination showed an ovarian malignant epithelial tumor. The operation was completed with type 2 hysterectomy, bilateral salpingooophorectomy, retroperitoneal lymph node dissection, rectosigmoid resection, low rectal anastomosis, pelvic peritonectomy, total omentectomy, splenectomy, diaphragm stripping and loop colostomy, and placement of two soft drains to the abdominal cavity. Prophylaxis for venous thromboemboli was provided with enoxaparin and compression stockings. The patient had stable hemodynamics [heart rate (HR) $86 \mathrm{bpm}$, blood pressure (BP) $120 / 70 \mathrm{mmHg}$, body temperature $36.7^{\circ} \mathrm{C}$, oxygen saturation with pulse oximetry $\left(\mathrm{SO}_{2}\right) 97 \%$, respiratory rate (RR) $16 / \mathrm{min}$, urinary output (UO): $100 \mathrm{cc} / \mathrm{hr}$ ] and was mobilized on postoperative $1^{\text {st }}$ day. There was gas passage through the colostomy once. On postoperative $2^{\text {nd }}$ day, the patient had dyspnea and cold sweats. In a physical examination, she had tachycardia and tachypnea, and bowel sounds were detected as hypoactive (HR: 120 bpm, BP: $120 / 80 \mathrm{mmHg}$, RR: 22/min, respiratory sounds normal, normoglycemic). The patient was admitted to intensive care unit. $\mathrm{SO}_{2}$ was measured $88 \%$ during follow-up and right costophrenic angle was appearing blunt in her chest X-ray. Arterial blood gas analysis results were as follows; ph: 7.41, $\mathrm{PCO}_{2}: 29.2 \mathrm{mmHg}, \mathrm{SO}_{2}: 86 \%, \mathrm{HCO}_{3}: 18.2 \mathrm{mmol} / \mathrm{L}$, and base excess (BE): $-4.9 \mathrm{mmol} / \mathrm{L}$. There was no additional feature in the blood cell counts and clinical biochemical tests. The diagnosis of pulmonary emboli was ruled out with thoracic spiral tomography. Adequate intravenous fluid resuscitation and oxygen support was provided to the patient. In the sequel, the patient began vomiting, while her bowel sounds remained hypoactive with the addition of abdominal distension. Her oral intake was stopped, and a urinary catheter was placed $(>100 \mathrm{cc} / \mathrm{hr})$. The fluid coming out of the abdominal drains was serous in appearance. Colostomy tract was open and abdominal x-ray was normal. In order to measure intravesical pressure (IVP) manually,(1) i.v. infusion set was filled with physiological serum completely. Zero point of the ruler $(30 \mathrm{~cm})$ was placed on the level of superior iliac crest, while the patient was in the supine position (central venous catheter manometer can also be used). Then, the bladder was filled with maximum 25 cc physiological serum (SF), and the urinary catheter was clamped. Next, the needle of the i.v. infusion set was inserted into the urinary catheter above the clamp. During late expiration, the infusion set was cut close to the pouch, and the fluid was allowed to drain off through gravity. The point it stabilized was noted as $\mathrm{cmH}_{2} \mathrm{O}\left(1 \mathrm{mmHg}=1.36 \mathrm{cmH}_{2} \mathrm{O}\right)$. The initial IVP was measured as $16 \mathrm{mmHg}\left(22 \mathrm{cmH}_{2} \mathrm{O}\right)$ and the nasogastric catheter was placed. Metoclopramide was administered intravenously with six hour intervals. The colostomy opening and rectum were touched at intervals to provide endoluminal decompression. Although there was no change in control arterial blood gas and laboratory analysis; the patient's dyspnea, tachypnea, tachycardia, and vomiting continued, and physical examination findings did not improve; IVP that measured two hours later was $21 \mathrm{mmHg}\left(28 \mathrm{cmH}_{2} \mathrm{O}\right)$. The patient was diagnosed with abdominal compartment syndrome, and decompressive laparotomy was performed. During the operation, there was minimal clear-appearing fluid in the abdominal cavity. The fluid was sampled for culture. All intestinal loops were dilated and filled the abdominal cavity completely. No obstruction, fistula or leakage of anastomosis was detected. The colostomy tract was open. The abdominal drains were replaced with new ones and decompression laparotomy was completed by closing the skin with mattress sutures without suturing the fascia. Antibiotic therapy was started intra-operatively. Endoluminal decompression was applied via the nasogastric catheter and by touch of colostomy opening and rectum. Adequate intravenous fluid resuscitation was provided, metoclopramide was continued as a prokinetic agent and total parenteral nutrition was administered.
During follow-up, the severity of dyspnea, tachypnea, tachycardia, and abdominal distention signs declined. IVP monitorization was started at postoperative $2^{\text {nd }}$ hour and continued with four hour intervals during the first 24 hours. IVP declined to $12 \mathrm{mmHg}$ at postoperative $18^{\text {th }}$ hour. Gas passage through colostomy started postoperative on the $1^{\text {st }}$ day and stool passage started on the $3^{\text {rd }}$ day. There was no bacterial growth in the culture of intraabdominal fluid. All of her abnormal signs improved on the $5^{\text {th }}$ day and enteral feeding was initiated. She made a full recovery on the postoperative 8th day. The patient completed six cycles of platinum-based chemotherapy during the next four months. After three months from completion of the chemotherapy, the loop colostomy was closed. Her overall condition was good, and follow-up has continued.

\section{DISCUSSION}

The mortality rates of IAH and ACS are $50-75 \%$, which can be reduced down to $34-37 \%$ with early diagnosis and the appropriate management ( 7 , 8). IAH/ACS may develop both in medical and surgical intensive care patients. Most common causes among adults include intraabdominal trauma, bleeding, and major abdominal surgery (9). Nevertheless, there are numerous etiologies and risk factors that include non-surgical and even iatrogenic causes (Table 1$)(2,6)$. Although clinical suspicion is important for diagnosis, symptoms in ACS do not have typical features. Therefore, sensitivity of clinical evaluation alone is quite low (40-56\%) (10). The simple gold-standard method for diagnosis is intravesical pressure (IVP) measurement that recommended by WSACS, on condition that bladder tumors and other conditions which create bladder compression are ruled out (11). The gastric and rectal pressure measurements can also be used for diagnosis, but they are less reliable than IVP (12). Although indications for measurement of IAP vary, current guidelines recommend IVP measurement for all critically ill or injured patients who have one or more risk factors (Table 1) for the development of IAH. Measurements should be performed every 4-6 hours until risk factors are resolved and IAP remains normal for 2448 hours $(2,3)$. Silva et al. emphasized that IAP should be measured routinely in intensive care units (13).

The main principle of its management is the determination of the underlying cause. Medical management is started when IAP is greater than $12 \mathrm{mmHg}$. In its medical management; enteral nutrition should be minimized or stopped, excessive fluid resuscitation should be avoided, pain should be controlled with analgesia and sedation, and patient's supine position should not exceed an angle of $30^{\circ}$ (2). Implementation of nasogastric or rectal tubes are not routinely recommended in all surgical patients; but if there is dilatation of stomach or intestines, those should be used for enteral decompression $(2,14)$. Use of promotility agents such as erythromycin and metoclopramide, is beneficial in the presence of paralytic ileus (3). Neuromuscular blocking agents such as neostigmine may be effective in treatment, because they induce colonic decompression and reduce the abdominal muscular tone; therefore, they decrease the abdominal compliance (2). Paracentesis and percutaneous drainage should be considered in the presence of intraabdominal fluid (1). Decompressive laparotomy $(D L)$ is required in the presence of $I A H$ that are refractory to medical therapy or ACS (3). DL reduces IAP immediately and improves the organ functions; however, the possibility of reperfusion damage should be kept in mind (15). Management after DL is very important. Planned incisional hernia that involves leaving the fascial defect open and closure of the skin only, is usually the safest solution if it is applicable without leading to an increase in IAP (16). Open abdomen techniques (OAT) can be used if it is thought that IAP would not be reduced (2). Bogota bag, Wittman patch, absorbable fascial meshes and modified vacuum pack sandwich technique are the most common OAT's (17). If not managed properly, serious complications can develop after OAT's, such as hemodynamic instability and hypothermia due to fluid evaporation, entero-atmospheric fistulae, sepsis due to contamination, erosion at intestinal wall, bleeding and loss of intestinal functions $(2,17)$.

The present case had three risk factors associated with ACS; obesity, history of major surgery and an elderly age. In our case, ACS was managed with DL which was terminated by closing the skin and leaving the fascia open that was defined as planned incisional hernia in literature. After secondary closure; medical management included adequate fluid resuscitation with avoiding positive balance, use of promotility agents such as metoclopramide, nasogastric tube insertion, intermittent rectal/colonic decompression, and percutaneous drain, while monitoring IVP every four hours. 
Table 1: Risk factors for intra-abdominal hypertension and abdominal compartment syndrome

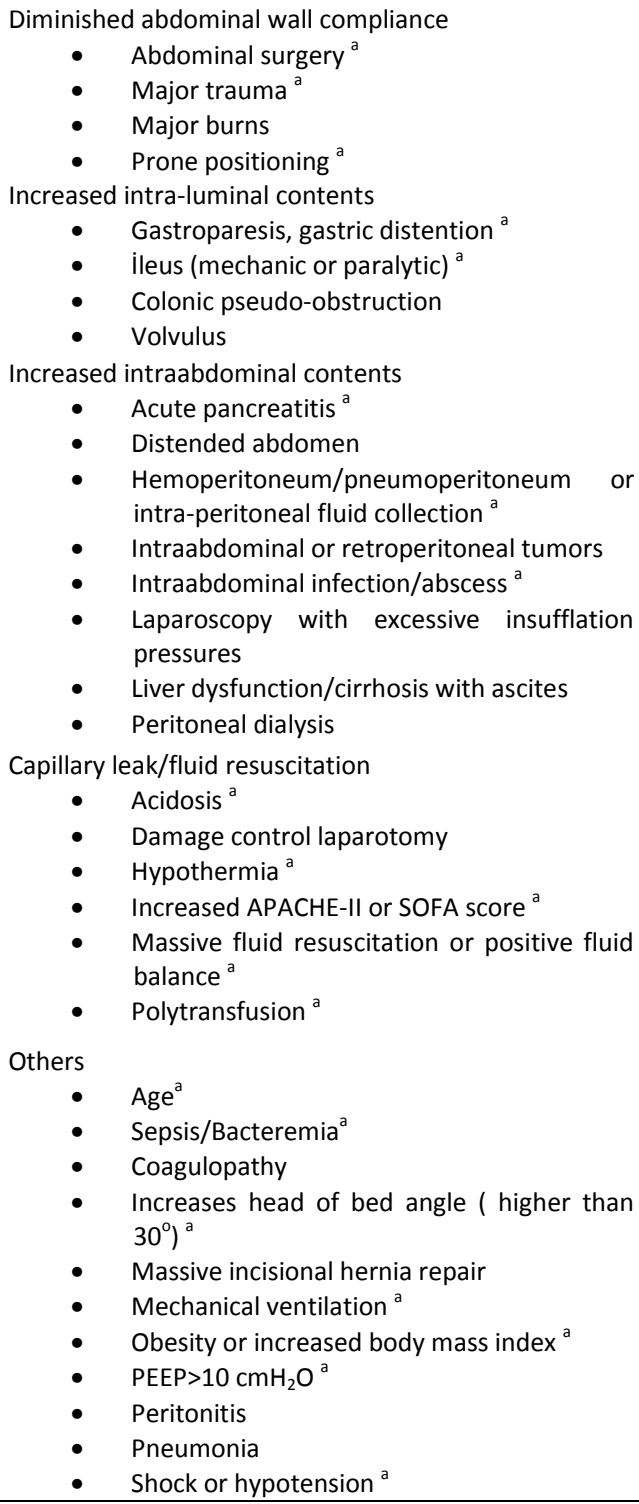

- Liver dysfunction/cirrhosis with ascites

- $\quad$ Peritoneal dialysis

Capillary leak/fluid resuscitation

- Acidosis $^{a}$

- Damage control laparotomy

- Hypothermia ${ }^{\mathrm{a}}$

- Increased APACHE-II or SOFA score ${ }^{\text {a }}$

- Massive fluid resuscitation or positive fluid balance $^{a}$

- Polytransfusion $^{\text {a }}$

Others

- $\mathrm{Age}^{\mathrm{a}}$

- Sepsis/Bacteremia ${ }^{a}$

- Coagulopathy

- Increases head of bed angle ( higher than $\left.30^{\circ}\right)^{\mathrm{a}}$

- Massive incisional hernia repair

- Mechanical ventilation ${ }^{a}$

- Obesity or increased body mass index ${ }^{\text {a }}$

- $\quad$ PEEP>10 $\mathrm{cmH}_{2} \mathrm{O}^{\mathrm{a}}$

- Peritonitis

- Pneumonia

- $\quad$ Shock or hypotension ${ }^{\text {a }}$

APACHE-II; acute physiology and chronic health evaluation-II

SOFA; sequential organ failure assessment

PEEP; positive end expiratory pressure

${ }^{a}$ indicates primary literature support

\section{CONCLUSION}

Early diagnosis helps to reduce morbidity and mortality significantly in $\mathrm{IAH}$ and ACS. Since sensitivity of clinical evaluation is low, it is thought that monitoring IAP with intermittent indirect IVP measurements in intensive care patients with high risk for ACS has great significance for early diagnosis, increasing the awareness for this condition. Early decompressive surgery in ACS is the life-saving step. Due to high complications rates, morbidity and mortality observed with open abdomen techniques; it is a convenient option to use the method involving closure of the skin only with leaving fascia open. After this implementation, close and attentive post-surgery medical management should be performed and IVP should be measured once in every four hours or continuously.

\section{Conflict of interest}

No conflict of interest was declared by the authors

\section{REFERENCES}

1.Scheppach W. Abdominal compartment syndrome. Best Practice \& Research Clinical Gastroenterology. 2009;23:25-33.

2.Kirkpatrick AW, Roberts DJ, De Waele J, Jaeschke R, Malbrain ML, De Keulenaer $B$, et al. Intra-abdominal hypertension and the abdominal compartment syndrome: updated consensus definitions and clinical practice guidelines from the World Society of the Abdominal Compartment Syndrome. Intensive care medicine. 2013;39:1190-206.

3.Malbrain ML, De Laet IE, De Waele JJ, Kirkpatrick AW. Intra-abdominal hypertension: definitions, monitoring, interpretation and management. Best practice \& research Clinical anaesthesiology. 2013;27:249-70.

4.Murtaza G, Pal KMI, Jajja MRN, Nawaz Z, Koondhar R, Nasim S. Intra abdominal hypertension; incidence, prevalence and outcomes in a mixed intensive care unit: Prospective cohort study. International Journal of Surgery. 2015;19:67-71.

5.Malbrain ML, Chiumello D, Pelosi P, Bihari D, Innes R, Ranieri VM, et al. Incidence and prognosis of intraabdominal hypertension in a mixed population of critically ill patients: a multiple-center epidemiological study. Critical care medicine. 2005;33:315-22.

6. Malbrain ML, Cheatham ML, Kirkpatrick A, Sugrue M, Parr M, De Waele J, et al. Results from the International Conference of Experts on Intraabdominal Hypertension and Abdominal Compartment Syndrome. I. Definitions. Intensive care medicine. 2006;32:1722-32

7.De Waele JJ, Leppaniemi AK. Intra-abdominal hypertension in acute pancreatitis. World journal of surgery. 2009;33:1128-33.

8.Carr J. Abdominal compartment syndrome: a decade of progress. J Am Coll Surg. 2013;216:135-46.

9.Hong JJ, Cohn SM, Perez JM, Dolich MO, Brown M, McKenney MG. Prospective study of the incidence and outcome of intra-abdominal hypertension and the abdominal compartment syndrome. The British journal of surgery. 2002;89:591-6.

10.Kirkpatrick AW, Brenneman FD, McLean RF, Rapanos T, Boulanger BR. Is clinical examination an accurate indicator of raised intra-abdominal pressure in critically injured patients? Canadian journal of surgery Journal canadien de chirurgie. 2000;43:207-11.

11.Saber A. Compartment syndromes. Journal of Acute Disease. 2014;3:16977.

12. Obeid F, Saba A, Fath J, Guslits B, Chung R, Sorensen V, et al. Increases in intra-abdominal pressure affect pulmonary compliance. Archives of surgery (Chicago, III : 1960). 1995;130(5):544-7; discussion 7-8.

13.Silva JP, Teles F. Assessment of intensivists' knowledge on abdominal compartment syndrome. Revista brasileira de anestesiologia. 2012;62:531-7. 14.Bauer JJ, Gelernt IM, Salky BA, Kreel I. Is routine postoperative nasogastric decompression really necessary? Annals of surgery. 1985;201:233-6.

15.De Waele J, Desender L, De Laet I, Ceelen W, Pattyn P, Hoste E. Abdominal decompression for abdominal compartment syndrome in critically ill patients: a retrospective study. Acta clinica Belgica. 2010;65:399403.

16.Tremblay LN, Feliciano DV, Schmidt J, Cava RA, Tchorz KM, Ingram WL, et al. Skin only or silo closure in the critically ill patient with an open abdomen. American journal of surgery. 2001;182(6):670-5.

17. Kreis BE, de Mol van Otterloo AJ, Kreis RW. Open abdomen management: a review of its history and a proposed management algorithm. Medical science monitor : international medical journal of experimental and clinical research. 2013;19:524-33. 